\title{
Analisis Faktor - Faktor yang Mempengaruhi Penyajian Kembali Laporan Keuangan
}

\author{
Budi Chandra ${ }^{1}$ \\ ${ }^{1}$ Universitas Internasional Batam \\ Email:budi.chandra@uib.ac.id
}

\begin{abstract}
ABSTRAK
Tujuan dari penelitian ini adalah untuk menguji karakteristik komite audit, leverage, jumlah anak perusahaan, persentase anak perusahaan asing, persentase direktur non-eksekutif, keahlian dewan direksi, ukuran dewan, dan pertumbuhan pada penyajian kembali laporan keuangan. pernyataan dengan menggunakan data perusahaan yang terdaftar di Bursa Efek Indonesia (BEI). Menggunakan metode purposive sampling yang memiliki beberapa kriteria untuk mengumpulkan data perusahaan dari 2014-2018 dan menguji data dengan metode uji regresi logistik. Kesimpulannya adalah bahwa ada pengaruh antara ukuran komite audit, jumlah anak perusahaan, dan persentase direktur non-eksekutif dengan penyajian kembali laporan keuangan. Sedangkan variabel independensi komite audit, rapat komite audit, keahlian komite audit, leverage, persentase anak perusahaan asing, keahlian dewan direksi, ukuran dewan, dan pertumbuhan tidak mempengaruhi penyajian kembali laporan keuangan.

Kata Kunci: penyajian kembali laporan keuangan, karakteristik komite audit
\end{abstract}

\begin{abstract}
The purpose of this study is to examine the characteristics of the audit committee, leverage, number of subsidiaries, percentage of foreign subsidiaries, percentage of non-executive directors, expertise of the board of directors, board size, and growth on the restatement of financial statements by using company data listed on the Indonesian Stock Exchange (IDX). Using a purposive sampling method that has several criteria to collect company data from 2014-2018 and test the data with the logistic regression test method. The conclusion is that there is an influence between the size of the audit committee, the number of subsidiaries, and the percentage of non-executive directors with the restatement of financial statements. While the audit committee independence variables, audit committee meetings, audit committee expertise, leverage, percentage of foreign subsidiaries, board of directors expertise, board size, and growth do not affect the restatement of financial statements.
\end{abstract}

Keywords: financial restatement, characteristics audit committee

\section{Pendahuluan}

Proses akuntansi yang berguna sebagai alat komunikasi atas aktivitas perusahaan dan pengukuran kinerja perusahaan kepada pihak yang berkepentingan merupakan pengertian dari laporan keuangan (Hery, 2016). Aturan No. 29/PJOK.04/2018 menyatakan laporan keuangan tahunan wajib dipublikasikan oleh setiap perusahaan terbuka (go public) (Otoritas Jasa Keuangan, 2016), laporan tersebut dapat memberikan informasi akurat dan jelas berupa kinerja perusahaan dan arus kas yang bisa dimanfaatkan untuk pembuatan keputusan ekonomi (Puspitasari \& Januarti, 2014). Namun, pada dasarnya perusahaan yang sudah dipublikasikan di BEI juga bisa terdapat penyajian kembali laporan keuangan (restatement).

Proses yang dilakukan untuk mengoreksi maupun revisi laporan keuangan yang sebelumnya terdapat kesalahan merupakan pengertian dari penyajian kembali laporan keuangan (Abdullah, Yusof, \& Nor, 2010). Penyajian kembali laporan keuangan 
adalah perusahaan harus melakukan penyajian ulang akibat adanya salah saji material dan perusahaan harus memberitahu kepada para investor agar mengetahui laporan tidak bisa lagi dijadikan sebagai acuan dalam mengambil keputusan (Puspitasari \& Januarti, 2014). Revisi tersebut akan ditampilkan pada laporan keuangan tahunan.

Perusahaan yang melakukan restatement bisa disebabkan karena adanya kesalahan yang telah direncanakan seperti menaikkan laba perusahaan untuk mencapai target yang ditetapkan, dan tidak disengaja berupa adanya perubahan standar akuntansi keuangan (Siregar \& Rahayu, 2018). Investor akan menilai perusahaan dari berbagai sisi sebelum melakukan investasi terutama akan melihat kinerja perusahaan, kinerja bisa saja dipengaruhi oleh restatement (Puspitasari \& Januarti, 2014). Perusahaan yang sering melakukan restatement akan memunculkan pertanyaan apakah penyebabnya berasal dari pihak eksternal maupun tata kelola perusahaannya tidak bagus.

Permasalahan perlakuan penyajian kembali laporan keuangan semakin dikenal oleh masyarakat (Widyaningrum \& Faisal, 2015), Kasus skandal penyajian kembali laporan keuangan yang terjadi di Indonesia yaitu, PT Garuda Indonesia Tbk (GIAA) menerbitkan laporan tahunan 2018 yang dinyatakan terdapat kenaikan laba yang melonjak tajam dari tahun 2017 yang masih menyatakan kerugian senilai 216,5 juta dolar Amerika, kenaikan laba tersebut berasal dari GIAA mengakui pendapatan atas piutang yang belum dibayarkan, sehingga angka laba pada tahun 2018 bisa mencapai 809,85 ribu dolar Amerika, sehingga laporan keuangan GIAA harus disajikan kembali untuk periode 2018 karena terdapat ketidaksesuaian dengan standar akuntansi yang ada (Tribunnews, 2019).

Konflik keagenan tercermin dari perusahaan melakukan restatement (Kusuma \& Rohman, 2014). Manajemen maupun para pemegang saham yang mementingkan kepentingan masing-masing pihak sehingga memunculkan adanya konflik. Teori keagenan merupakan hubungan antar pihak agen dengan pihak principal yang disajikan dalam bentuk kontrak (Jensen \& Meckling, 1976). Konflik keagenan bisa muncul dikarenakan beberapa faktor yang mempengaruhi yaitu komite audit (Amin, 2016).

Komite audit diwajibkan oleh OJK untuk dibentuk (Ayu \& Septiani, 2018). Pembentukan komite audit dipilih oleh dewan komisaris dengan tujuan agar komite audit membantu dewan komisaris dalam mengawasi perusahaan (Tandungan \& Mertha, 2016). Selain itu, komite audit juga dibentuk untuk melakukan pengawasan dan membantu tim manajemen dan direktur, serta melakukan pemantauan terhadap perusahaan dalam menerapkan prinsip tata kelola perusahaan yang benar dan baik (Handoko \& Ramadhani, 2017).

Independensi dalam komite audit dapat diartikan sebagai sebuah sifat mandiri ataupun tidak ada berhubungan antara anggota terhadap pejabat dalam perusahaan (Apadore \& Noor, 2013). Sesuai dengan aturan yang tercantum dalam OJK nomor 55/P0JK.04/2015 perusahaan memiliki kewajiban dalam mendirikan komite audit yang bukan termasuk pihak yang bersangkutan dengan perusahaan atau anggota yang berasal dari luar usaha. Komite audit yang banyak dan bersifat independensi akan mengurangi perusahaan melakukan penyajian kembali laporan keuangan karena pihak komite audit akan melakukan pengawasan secara efektif dan tidak dipengaruhi oleh pihak manajemen (Widyaningrum \& Faisal, 2015), sehingga pada saat ketemu adanya ketidaksesuaian dalam penyajian laporan keuangan akan diminta untuk 
melakukan penyajian kembali. Dengan begitu, laporan keuangan yang dibuat perusahaan lebih bisa diandalkan oleh para pengguna (Hashim \& Rahman, 2011).

\section{Hipotesis}

$\mathrm{H}_{1}$ : Independensi komite audit berpengaruh signifikan negatif terhadap penyajian kembali laporan keuangan.

Komite audit melaksanakan pertemuan guna untuk memantau, diskusi dan implementasi strategi serta untuk berkonsultasi bersama dan memberikan pendapat dalam mendeteksi penyimpangan pelaporan Mohammad et al. (2018). Pertemuan antar anggota komite yang semakin banyak akan mengurangi kemungkinan terjadinya penyajian kembali laporan keuangan, hal ini karena pada saat rapat akan terdapat pembahasan tentang proses laporan keuangan dan cara penyelesaian masalah yang ditemukan, sehingga dapat mencari solusi dalam penyelesaian permasalahan dengan mengemukakan pendapatan masing-masing anggota. Menurut ketentuan 0JK nomor 55/POJK.04/2015 yang mengatur komite audit wajib melakukan rapat dengan sesama anggota paling tidak tiga bulan sekali (Amalia \& Didik, 2017).

$\mathrm{H}_{2}$ : Rapat komite audit berpengaruh signifikan negatif terhadap penyajian kembali laporan keuangan.

Anggota komite audit diwajibkan oleh OJK untuk dibentuk dengan anggota minimal terdapat atas tiga anggota yang ketuanya dipilih dari dewan komisaris independen dan dua anggota lagi yang merupakan orang eksternal atau pihak luar yang tidak berafiliasi (Pembayun \& Januarti, 2012). Pembentukan komite audit memiliki peluang yang lebih besar dalam peninjauan keuangan perusahaan, serta fungsi pada komite audit berupa perlakuan pemantauan terhadap perusahaan agar tetap mematuhi aturan yang ada, komite audit juga bertugas dalam melakukan internal kontrol, kemampuan perusahaan untuk menghadapi risiko, dan menangani keluhan dari konsumen (M \& Laksito, 2017). Ukuran komite audit yang semakin besar cenderung akan menurunkan persentase adanya penyajian kembali laporan keuangan karena banyaknya anggota dapat mempermudah tiap anggota dalam hal pembagian tugas akan jelas serta tidak mencakup luas dengan begitu anggota komite audit akan fokus dan lebih efektif pada mengawasi adanya proses aktivitas perusahaan.

$\mathrm{H}_{3}$ : Ukuran komite audit berpengaruh signifikan negatif terhadap penyajian kembali laporan keuangan.

Kemahiran komite audit menjadi sesuatu yang penting dalam membantu menjaga adanya keefektivitasan. Kemahiran pada komite audit merupakan suatu kewajiban yang sudah ditetapkan dalam aturan OJK (Pembayun \& Januarti, 2012). Dalam pembentukan komite audit diharuskan terdapat paling tidak satu anggota yang mempunyai pengalaman dalam aspek keuangan maupun akuntansi, dengan begitu, komite audit dapat memahami cara pengauditan laporan oleh auditor, memahami kebijakan dalam akuntansi serta memahami kompleksitas laporan keuangan (Dwiharyadi, 2017). Perusahaan yang memiliki tingkat persentase anggota yang tinggi dan memiliki kemahiran yang profesional maka tingkat kemungkinan penyajian kembali akan rendah, hal ini karena komite audit memahami dan dapat mendeteksi laporan keuangan yang memiliki kesalahan maupun yang melanggar aturan sehingga pada saat itu komite audit dapat membenarkannya. 
$\mathrm{H}_{4}$ : Keahlian keuangan komite audit berpengaruh signifikan negatif terhadap penyajian kembali laporan keuangan.

Rasio yang digunakan dalam menaksir banyaknya peluang perusahaan untuk melunasi hutangnya (Ibrahim \& Suryaningsih, 2016). Rasio digunakan untuk menghitung berapa banyak persentase hutang dan aset yang ada pada perusahaan. Persentase tingkat hutang pada perusahaan yang semakin tinggi cenderung dapat meningkatkan kemungkinan penyajian kembali, sebab tingkat hutang yang tinggi pada perusahaan akan mendorong manajemen perusahaan untuk melakukan cara supaya tetap memiliki investor yang mau menginvestasikan saham mereka. Dimana tingkat hutang tersebut menggambarkan perusahaan tidak mampu melakukan pembayaran hutang sehingga melakukan manipulasi hasil keuangan untuk menarik perhatian investor maupun kreditur untuk mengeluarkan dana untuk menjalankan aktivitas perusahaan.

$\mathrm{H}_{5}$ : Leverage berpengaruh signifikan positif terhadap penyajian kembali laporan keuangan.

Perusahaan yang berkembang dalam bisnisnya akan ingin memperluas usahanya sehingga mendirikan anak perusahaan yang dikendali oleh perusahaan induk (Cristansy \& Ardiati, 2018). Immanuel dan Yuyetta (2014) mengatakan bahwa tidak perlu melakukan bisnis dan ditempat yang sama karena perusahaan induk dan anak merupakan usaha yang terpisah. Laporan yang dihasilkan oleh setiap anak perusahaan akan dijadikan satu bersama laporan pusat sesuai dengan peraturan yang mengatur tentang entitas anak perusahaan. Semakin banyak anak perusahaan maka dalam hal pengawasan laporan keuangan juga rumit sehingga kemungkinan terjadinya kesalahan dalam penyajian akan tinggi karena anak perusahaan yang banyak dalam hal melakukan pemantauan akan semakin luas dan pastinya ada tidak semua perusahaan dapat diawasi dengan baik.

$\mathrm{H}_{6}$ : Jumlah anak perusahaan berpengaruh signifikan positif terhadap penyajian kembali laporan keuangan.

Dimana perusahaan induk mendirikan perusahaan anak di luar kota dan perusahaan tersebut tetap dikendalikan oleh perusahaan induk. Perusahaan yang berada di luar tidak bisa mengikuti aturan seperti perusahaan induk karena harus mengikuti aturan sesuai dengan negara yang dijadikan sebagai tempat berinvestasi. Jumlah anak perusahaan asing yang semakin banyak akan meningkatkan kemungkinan restatement, hal ini karena entitas anak perusahaan asing memiliki peraturan masingmasing dan pemantauan hanya bisa dilakukan secara terbatas karena posisinya jauh.

$\mathrm{H}_{7}$ : Persentase jumlah anak perusahaan asing berpengaruh signifikan positif terhadap penyajian kembali laporan keuangan.

Direksi dipilih oleh pemegang saham untuk membantu dalam hal mengawasi dan menjalankan kegiatan perusahaan serta direksi tidak memihak pada siapapun atau bersifat independensi (Ridwan \& Afriyenti, 2019). Anggota direksi independen juga diwajibkan oleh aturan OJK nomor 33/POJK.04/2014 tidak berhubungan dengan setiap pemegang saham ataupun bersifat afiliasi. Direktur tidak tunduk pada pemegang saham pengendali, sehingga mereka memiliki keuntungan dalam mengawasi manajemen dan dapat membuat penilaian independen. Perusahaan 
dengan proporsi tinggi direktur independen lebih cenderung untuk mengungkapkan lebih banyak informasi keuangan, sehingga kualitas informasi akuntansi relatif tinggi, dan kemungkinan penyajian kembali keuangan lebih kecil.

$\mathrm{H}_{8}$ : Persentase direktur non eksekutif berpengaruh signifikan negatif terhadap penyajian kembali laporan keuangan.

Selama ini Kantor Akuntan Publik atau KAP besar yang melakukan tugas audit pada laporan keuangan perusahaan sangat dipercaya dan memiliki kualitas yang sangat tinggi. Jika seorang direksi juga pengalaman kerja dalam KAP big four akan dipandang bagus oleh investor karena investor percaya bahwa pengalaman yang didapatkan dari bekerja ditempat KAP akan sangat membantu perusahaan dalam mengatur dan melakukan pengawasan sehingga laporan yang dihasilkan nantinya juga akan terpercaya dan berkualitas. Keahlian dewan direksi yang tinggi akan mengurangi kemungkinan penyajian kembali laporan keuangan, karena direksi yang memiliki pengalaman pada KAP besar akan memiliki banyak pemahaman tentang proses pelaporan keuangan sehingga mengetahui dan lebih bisa mendeteksi adanya kesalahan pada saat penyajian laporan keuangan. Terdapat 4 KAP besar pada Indonesia diantaranya (Harijanto, 2019):

1. KAP Purwantono, Sarwoko, Sandjaja berafiliasi dengan Ernst \&Young.

2. KAP Osman Bing Satrio dan Rekan berafiliasi dengan Deloitte Touche Tohmatsu.

3. KAP Siddharta dan Widjaja berafiliasi dengan Klynveld Peat Marwick Goerdeler (KPMG).

4. KAP Tanudireja Wibisana \& Rekan berafiliasi dengan Pricewaterhouse Coopers.

H9: Keahlian dewan direksi memiliki berpengaruh negatif terhadap penyajian kembali laporan keuangan.

Setiap perusahaan pasti mempunyai beberapa orang yang berjabat sebagai direksi, dan direksi tersebut mempunyai tanggung jawab dalam mengelola perusahaan sesuai dengan tujuan yang akan dicapai. Banyaknya jumlah direksi akan membawa bentuk pengawasan terhadap kinerja perusahaan yang lebih baik, Perusahaan yang memiliki jumlah dewan direksi yang banyak akan mudah dikendalikan dan pengawasan juga akan semakin efektif sehingga akan mengurangi kemungkinan penyajian kembali laporan keuangan.

$\mathrm{H}_{10}$ : Board Size memiliki berpengaruh negatif terhadap penyajian kembali laporan keuangan.

Growth berupa rasio yang dimanfaat untuk melihat berapa besar saham yang di pasaran dibanding dengan nilai buku saham. Pemandangan growth didasarkan besarnya harga saham yang terjual dibandingkan dengan nilai buku. Growth yang digunakan adalah market to book value yang mengindikasikan pandangan investor terhadap nilai perusahaan. Dana yang berasal dari investor, kreditur dan pemangku kepentingan lain terhadap situasi yang dihadapi perusahaan disebut market value. Jadi market value disini berupa saham yang harus dibeli kembali oleh perusahaan untuk mengendalikan perusahaan secara penuh sedangkan nilai buku adalah nilai yang berasal dari hutang, ekuitas dan kekayaan perusahaan yang berasal dari pencatatan masa lalu dan dapat di lihat pada laporan posisi keuangan (Setiawan \& Mahardika, 2019). 
$\mathrm{H}_{11}$ Growth memiliki berpengaruh positif terhadap penyajian kembali laporan keuangan.

\section{Metode Penelitian \\ Rancangan Penelitian}

Penelitian kausal komparatif merupakan penelitian dengan melihat permasalahan yang diteliti, yaitu adanya hubungan sebab akibat. Penelitian ini bersifat kuantitatif dengan memakai nominal tertentu dalam mengukur dan analisis data sesuai proses statistik. Tujuan perlakuan penelitian untuk mengembangkan dan berharap penelitian tersebut bisa membawa manfaat kepada pihak yang berkepentingan serta menilai konsep teoretis (Indriantoro \& Supomo, 2013). Penulis menggunakan data yang bersifat sekunder yang berasal dari perusahaan yang sudah terdaftar pada BEI mulai dari tahun 2014 - 2018 yang bisa ditemukan pada situs www.idx.co.id.

Pada penelitian tersebut diharapkan dapat mengetahui apakah terdapat pengaruh berupa variabel independensi komite audit, rapat komite audit, ukuran komite audit, keahlian komite audit, leverage, jumlah anak perusahaan, persentase jumlah anak perusahaan asing, persentase direktur non eksekutif, keahlian dewan direksi, board size, growth terhadap penyajian kembali laporan keuangan.

\section{Definisi Operasional Variabel}

Variabel dependen adalah variabel yang akan diteliti untuk mengetahui variabel mana yang akan mempengaruhi dependen (Sugiyono, 2016). Variabel dependen yang akan diuji adalah penyajian kembali laporan keuangan dimana dalam pengukuran tersebut menggunakan skala nominal yaitu:

Restatement = 1 jika menunjukkan terjadinya penyajian ulang sebaliknya juga jika angka 0 maka tidak terjadi penyajian ulang pada laporan perusahaan.

\section{Variabel independen}

Variabel independen atau variabel bebas yaitu variabel tersebut bisa memengaruhi variabel dependen. Variabel independen yang digunakan sebagai berikut:

\section{Independensi Komite Audit}

Pada dasarnya independensi anggota audit komite dibentuk karena adanya perintah dari OJK. Perusahaan diharuskan terdapat minimal satu orang yang merupakan pihak dari eksternal. Untuk melihat data apakah anggota komite audit bersifat independen atau tidak terdapat pada catatan laporan tahunan yang berupa penjelasan tentang komite audit. Pengukuran independensi komite audit dengan cara:

$$
\text { Independensi komite audit }=\frac{\text { jumlah anggota komite audit independen }}{\text { jumlah anggota komite audit }}
$$

\section{Rapat Komite Audit}

Rapat komite audit bermanfaat dalam hal pemantauan manajemen yang efektif, diskusi strategi dan implementasi, serta kemampuan bagi para direktur untuk berkonsultasi bersama dan berbagi pendapat, sehingga pada saat ketemu masalah dapat menjadi bahan diskusi serta mencari cara mengatasinya dan pembuatan 
keputusan dengan mengumpulkan pendapat masing-masing sehingga menghasilkan satu keputusan. Rumus yang digunakan:

Rapat komite audit $=$ jumlah pertemuan komite audit

\section{Ukuran Komite Audit}

Berdasarkan aturan dari OJK No.55/POJK.04/2015 membuat aturan bahwa setiap perusahaan diwajibkan untuk mempunyai anggota audit pada perusahaan paling sedikit tiga anggota yang diketuai oleh dewan komisaris independen dari perusahaan dan dua orang yang tidak adanya hubungan dengan orang dalam perusahaan dan bersifat independen, sehingga pada saat mengawasi tata cara pelaporan keuangan maupun kinerja perusahaan komite audit tidak memihak pada siapapun. Pengukuran untuk variabel ukuran komite audit berupa:

Ukuran komite audit $=$ jumlah anggota komite audit

\section{Keahlian Komite Audit}

Berdasarkan peraturan OJK No. 55 /POJK.04/2015, anggota komite audit selain diwajibkan bersifat independensi juga harus terdapat seorang yang memiliki pengetahuan maupun ilmu dalam aspek akuntansi ataupun aturan lainnya. Anggota komite audit mampu memahami proses audit, manajemen risiko, dan peraturan undang - undang dibidang pasar modal serta peraturan audit lainnya, agar bisa melakukan pengawasan yang bagus dalam hal tata kelola perusahaan. Variabel keahlian komite audit diukur dengan:

Keahlian komite audit $=$ anggota berkeahlian dalam keuangan dan akuntansi

\section{Leverage}

Leverage adalah rasio yang dipakai untuk membandingkan kondisi perusahaan antar kewajiban dan aset yang ada. Penghitungan leverage dapat dilakukan dengan rumus yaitu:

$$
\text { Leverage }=\frac{\text { total hutang }}{\text { total aktiva }}
$$

\section{Jumlah Anak Perusahaan}

Perusahaan besar yang berdiri lama akan ingin memperluas atau mencari untung lebih banyak dan bukan melakukan satu bisnis saja, sehingga mendirikan anak perusahaan yang semua aktivitas maupun laporan keuangan-nya akan dilakukan konsolidasi dengan laporan pusat. Anak perusahaan yang didirikan oleh perusahaan induk tidak perlu memiliki produk, lokasi yang sama tetapi bisa berbeda-beda yang penting bisa membawa keuntungan bagi perusahaan. Variabel ini diukur berdasarkan:

Jumlah anak perusahaan $=\log$ jumlah entitas anak perusahaan 


\section{Persentase Anak Perusahaan Asing}

Perusahaan yang semakin besar akan ingin produk yang dihasilkan juga dikenal di luar kota sehingga mendirikan perusahaan di kota lain guna bisa lebih menghemat biaya-biaya dan membuat nama perusahaan terkenal juga di luar kota. Perusahaan yang berada di luar kota tetap dikendalikan oleh perusahaan tetapi pada sistem pelaporan keuangan akan tetap sama supaya dapat dibandingkan. Pengukurannya berupa:

$$
\text { Persentase anak perusahaan asing }=\frac{\text { anak perusahaan asing }}{\text { jumlah anak perusahaan }}
$$

\section{Persentase Direktur Non Eksekutif}

Suatu perusahaan yang tercatat di BEI banyak ketentuan yang harus di patuhinya, antara lain pada jajaran pengurusnya harus mempunyai direktur independen. Direktur Independen menjadi anggota dewan direksi yang bertanggung jawab atas jalannya perusahaan setiap hari. Dimana direktur independen adalah orang yang memiliki kemampuan namun tidak punya hubungan keluarga maupun hubungan bisnis dengan pemilik saham perusahaan atau dengan salah satu pengurus. Data dewan direksi yang bersifat tidak afiliasi dapat dilihat pada bagian catatan laporan keuangan yang terdapat susunan untuk para anggota dewan komisaris, direksi, dan komite audit, pengukurannya:

$$
\text { Persentase direktur non eksekutif }=\frac{\text { jumlah direktur independen }}{\text { jumlah direktur }}
$$

\section{Keahlian Dewan Direksi}

Akuntan yang terpercaya dan terkenal dengan kualitas pengauditan laporannya adalah the big four. Laporan yang diaudit oleh salah satu dari keempat auditor tersebut akan meningkatkan kualitas audit dan kepercayaan investor dalam melihat laporan yang telah disajikan. Begitu juga dengan orang yang memiliki pengalaman kerja dalam empat KAP besar tersebut. Direktur yang diangkat dan memiliki pengalaman dalam KAP besar ini akan membawa pengawasan yang lebih bagus dan sangat memahami aturan yang tidak boleh dilanggar, sehingga pada saat melakukan proses pengawasan laporan keuangan akan terpantau jika terjadi kesalahan maupun yang tidak sesuai dengan aturan. Variabel ini diukur berdasarkan jumlah dewan direksi yang memiliki pengalaman kerja di KAP besar (the big four).

\section{Keahlian dewan direksi = direksi yang berpengalaman bekerja di KAP besar}

\section{Board Size}

Direksi merupakan orang yang dipilih oleh para pemegang saham untuk membantu dalam hal melakukan pengawasan terhadap perusahaan. Direksi juga memiliki tanggung jawab yang perlu dicapainya berupa visi dan misi yang sudah ditetapkan dari awal perusahaan berdiri. Jumlah dewan direksi dapat dilihat pada laporan keuangan. Pengukuran yang digunakan adalah:

$$
\text { Board size }=\log \text { jumlah dewan direksi }
$$




\section{Growth}

Growth berupa Rasio yang dimanfaatkan dalam mengukur banyaknya harga pasar saham dibanding dengan nilai buku. Pengukuran growth dapat dilakukan dengan:

$$
\text { Growth }=\frac{\text { harga pasar saham }}{\frac{\text { jumlah ekuitas }}{\text { jumlah saham beredar }}}
$$

\section{Hasil Dan Pembahasan}

\section{Statistik Deskriptif}

Hasil statistik deskriptif penelitian ini adalah sebagai berikut:

Tabel 1. Statistik deskriptif untuk variabel dummy

\begin{tabular}{|l|r|r|r|r|}
\hline & Frekuensi & Persentase & $\begin{array}{c}\text { Persentase } \\
\text { Valid }\end{array}$ & $\begin{array}{c}\text { Persentase } \\
\text { Kumulatif }\end{array}$ \\
\hline Non & 1,586 & 72,0 & 72,0 & 72,0 \\
Restatement & 618 & 28,0 & 28,0 & 100,0 \\
Restatement & 2,204 & 100,0 & 100,0 & \\
Total & & & \\
\hline
\end{tabular}

Tabel 2. Statistik deskriptif untuk variabel rasio

\begin{tabular}{cccccc}
\hline \hline Variabel & $\mathbf{N}$ & Minimum & Maksimum & Rata-rata & Std. Deviasi \\
\hline AUCI & 2204 & 0,7500 & 1,0000 & 0,9992 & 0,0138 \\
NOAM & 2204 & 0,0000 & 61,0000 & 6,9036 & 6,4864 \\
ACSIZE & 2204 & 1,0000 & 7,0000 & 3,1103 & 0,5228 \\
NOEXPERT & 2204 & 0,0000 & 6,0000 & 2,5290 & 0,8450 \\
LEV & 2204 & 0,0002 & 19,9701 & 0,6148 & 0,9540 \\
SUB & 2204 & 0,0000 & 2,6637 & 0,6329 & 0,5782 \\
FORE & 2204 & 0,0000 & 1,0000 & 0,0924 & 0,2016 \\
OUTSIDER & 2204 & 0,0000 & 1,0000 & 0,2271 & 0,1700 \\
BEXPERT & 2204 & 0,0000 & 3,0000 & 0,1724 & 0,4274 \\
BSIZE & 2204 & 0,3010 & 1,2041 & 0,6457 & 0,1810 \\
GROWTH & 2204 & $-21819,1003$ & 368,5549 & $-7,5814$ & 465,3229 \\
\hline \hline
\end{tabular}




\section{Hasil Uji Multikolinearitas}

Pengujian hasil multikolinearitas terdapat pada tabel dibawah ini:

Tabel 3. Uji Multikolinearitas

\begin{tabular}{lcc}
\hline & Model & \multicolumn{2}{c}{ Collinearity Statistic } \\
& Tolerance & VIF \\
AUCI & 0,916 & 1,092 \\
NOAM & 0,843 & 1,186 \\
ACSIZE & 0,630 & 1,588 \\
NOEXPERT & 0,717 & 1,395 \\
LEV & 0,995 & 1,005 \\
SUB & 0,885 & 1,130 \\
FOREIGN & 0,959 & 1,042 \\
OUTSIDER & 0,798 & 1,254 \\
BEXPERT & 0,954 & 1,048 \\
BSIZE & 0,674 & 1,483 \\
GROWTH & 0,997 & 1,003 \\
\hline \hline
\end{tabular}

Dari hasil uji diatas terlihat data secara keseluruhan terdapat adanya multikolinearitas atau tidak. Dari data yang didapatkan dapat membuat kesimpulan bahwa dari semua variabel independen yang dijadikan sebagai pengujian tidak terdapat multikolinearitas dengan melihat nilai VIF berada dibawah angka 10 dan tolerance pada semua variabel independen melebihi angka 0,10 .

\section{Hasil Uji Hosmer and Lemeshow Test}

Tabel 4. Hasil Uji Hosmer and Lemeshow Test

\begin{tabular}{cccc}
\hline \hline Variabel Dependen & Chi-square & Sig & Kesimpulan \\
\hline Restatement & 11,414 & 0,179 & Model diterima \\
\hline \hline
\end{tabular}

Data diatas menunujukkan hasil uji hosmer and lemeshow test dengan tingkat signifikansi berada pada angka 0,179 yaitu telah melebihi 0,05 sehingga disimpulkan model tersebut bisa dilanjuti untuk dilakukan penelitian. Hasil uji tersebut juga memberikan bukti bahwa model regresi pada penelitian ini bisa dimanfaatkan untuk memprediksi adanya faktor yang membawa pengaruh kepada penyajian kembali laporan keuangan.

\section{Hasil Uji Nagelkerke R Square (Model Summary)}

Uji nagelkerke R square bertujuan dalam pengujian persentase kecocokan model yaitu dimana model yang diteliti bisa menggambarkan variabel dependen. Hasil uji nagelkerke $R$ square ditampilkan pada tabel sebagai berikut: 
Tabel 5. Hasil Nagelkerke R Square

\begin{tabular}{cc}
\hline \hline Variabel Dependen & Nagelkerke $\boldsymbol{R}$ Square \\
\hline Restatement & 0,025 \\
\hline \hline
\end{tabular}

Hasil pengujian nagelkerke $R$ square diatas memberikan gambaran dengan nilai nagelkerke $R$ square sebesar 0.025 atau $2.5 \%$ dalam arti variabel yang dijadikan sebagai variabel independen pada penelitian tersebut dapat memberikan penjelasan terhadap variabel penyajian kembali laporan keuangan sebesar 2,5\% sedangkan sisanya 97,5\% dijelaskan oleh variabel-variabel maupun ada faktor lain yang tidak diambil penulis dalam melakukan pengujian.

\section{Hasil Uji Variables in the Equation (Uji Wald)}

Uji variables in the equation atau uji wald berguna sebagai suatu pengujian yang bertujuan melihat apakah variabel yang digunakan bisa mempengaruhi variabel lainnya. Hasil pengujian terdapat pada tabel sebagai berikut:

Tabel 6 Hasil variables in the equation (uji wald)

\begin{tabular}{lccccc}
\hline \multicolumn{1}{c}{ Variabel } & B & Wald & Sig & Kesimpulan & Hipotesis \\
\hline C & $-2,650$ & 0,458 & 0,499 & & \\
AUCI & 1,134 & 0,087 & 0,768 & Tidak Signifikan & Tidak terbukti \\
NOACM & $-0,002$ & 0,089 & 0,765 & Tidak Signifikan & Tidak terbukti \\
ACSIZE & 0,346 & 9,549 & 0,002 & Signifikan positif & Tidak terbukti \\
NOEXPERT & $-0,022$ & 0,105 & 0,745 & Tidak Signifikan & Tidak terbukti \\
LEV & $-0,136$ & 2,963 & 0,085 & Tidak Signifikan & Tidak terbukti \\
SUB & 0,323 & 13,756 & 0,000 & Signifikan positif & Terbukti \\
FOREIGN & 0,417 & 3,220 & 0,073 & Tidak Signifikan & Tidak terbukti \\
OUTSIDER & $-0,821$ & 6,324 & 0,012 & Signifikan negatif & Terbukti \\
BEXPERT & $-0,116$ & 0,980 & 0,322 & Tidak Signifikan & Tidak terbukti \\
BSIZE & $-0,625$ & 3,710 & 0,054 & Tidak Signifikan & Tidak terbukti \\
GROWTH & 0,000 & 1,150 & 0,699 & Tidak Signifikan & Tidak terbukti \\
\hline \hline
\end{tabular}

Pada tabel diatas menggambarkan hasil penelitian yaitu ukuran audit komite, jumlah anak perusahaan, persentase direktur non eksekutif memiliki hubungan signifikan terhadap restatement laporan keuangan dengan nilai signifikan berturut turut $0,002,0,000,0,012$ dengan nilai dibawah 0,05 sedangkan variabel independensi komite audit, rapat komite audit, keahlian keuangan komite audit, leverage, persentase jumlah anak perusahaan asing, keahlian dewan direksi, board size, growth tidak memiliki hubungan yang signifikan terhadap penyajian kembali laporan keuangan dengan nilai signifikan diatas 0,05.

Hasil $\mathrm{H}_{1}$ menunjukan angka signifikansi 0,768 sehingga tidak membuktikan independensi komite audit berpengaruh terhadap restement. Komite audit tidak dapat menjamin dapat mengurangi adanya perlakuan restatement karena sesuai dengan aturan dari OJK setiap perusahaan telah membentuk independensi komite audit yang berasal dari pihak luar sehingga tidak ada pembeda yang bisa melihat perusahaan yang 
memang memanfaatkan independensi dalam menjalankan tugasnya atau hanya untuk memenuhi peraturan yang berlaku, maka $\mathrm{H}_{1}$ ditolak.

Hasil $\mathrm{H}_{2}$ memiliki nilai signifikansi 0,765 yang berarti tidak terbukti rapat komite audit dapat mempengaruhi penyajian kembali laporan keuangan. Komite audit melakukan pertemuan guna untuk menyelesaikan masalah dan membahas proses kerja terhadap laporan keuangan. Pertemuan yang dilakukan oleh para anggota komite audit memunculkan beberapa pendapatan dan cara penyelesaian masalah, jika hasil dari pertemuan tersebut tidak ditindaklanjuti oleh dewan komisaris maka tidak ada dampaknya terhadap perubahan pada perusahaan sehingga seberapa banyak maupun sedikitnya rapat yang dilakukan oleh anggota komite audit jika tidak ditangani oleh dewan komisaris sama aja tidak mendapatkan pengaruhnya, maka $\mathrm{H}_{2}$ ditolak.

Hasil uji $\mathrm{H}_{3}$ mendapatkan nilai signifikan 0,002 dan koefisiennya terdapat 0,346 yang dapat menjelaskan adanya hubungan signifikan positif antara komite audit dan restatement laporan keuangan. Anggota yang berlebihan akan semakin memungkinkan perusahaan melakukan penyajian kembali karena anggota komite audit yang berlebihan akan membuat pengawasan menjadi tidak efektif sehingga terdapat kelalaian yang tidak dipantau . maka $\mathrm{H}_{3}$ ditolak.

Hasil uji $\mathrm{H}_{4}$ menyatakan nilai signifikan 0,745 lebih dari 0,05 maka keahlian komite audit tidak terbukti mempunyai pengaruh terhadap penyajian kembali laporan keuangan. Perusahaan yang memiliki keahlian komite audit tidak cukup teliti maupun dikarenakan banyak faktor yang mempengaruhi misalnya menganggap itu kurang materialistis, dan pengawasan yang terbatas sehingga meskipun para anggota komite audit yang memiliki pengalaman, jika dalam hal anggota komite audit yang berpengalaman cuma satu orang dan tidak dimanfaatkan dengan baik maka tidak akan efektif dalam melakukan pengawasan terhadap laporan keuangan maka $\mathrm{H}_{4}$ ditolak.

Dari hasilnya terdapat nilai 0,085 yang tidak memberikan bukti adanya pengaruh signifikan terhadap penyajian kembali laporan keuangan. Perusahaan yang memiliki hutang kecil maupun besar itu bergantung pada cara perusahaan memanfaatkan uang yang berasal dari hutang tersebut untuk menjalankan aktivitas perusahaan maupun uang yang berasal dari kreditur. Jadi seberapa besar kecilnya hutang tidak mempengaruhi proses pembuatan laporan keuangan, maka $\mathrm{H}_{5}$ ditolak.

Hasil uji dari $\mathrm{H}_{6}$ bernilai 0,000 yang terbukti bahwa jumlah anak perusahaan berpengaruh signifikan positif terhadap penyajian kembali laporan keuangan. Perusahaan yang mempunyai anak perusahaan yang banyak akan meningkatkan kemungkinan restatement, dikarenakan perusahaan yang mempunyai jumlah anak perusahaan akan menggabungkan semua laporan keuangan yang sudah dibuat oleh akuntan masing-masing perusahaan anak ke pusat sehingga bisa memungkinkan adanya kesalahan material yang perlu dilakukan penyajian kembali dengan begitu $\mathrm{h}_{6}$ diterima.

Hasil pengujian ini melebihi 0,05 dengan angka 0,073 yang tidak terbukti dapat mempengaruhi penyajian kembali laporan keuangan, hal ini karena perusahaan yang berada pada negara asing akan mengikuti peraturan yang ada disana maupun dari sisi sampel dapat dilihat perusahaan yang ada pada Indonesia sangat jarang mendirikan perusahaan di negara asing sehingga tidak dapat mempengaruhi penyajian kembali laporan keuangan, maka $\mathrm{H}_{7}$ ditolak.

Hasil dari $\mathrm{H}_{8}$ adalah 0,012 dapat disimpulkan terdapat pengaruh signifikan negatif antara direktur non eksekutif dan penyajian kembali laporan keuangan. Direksi independen yang banyak akan melakukan pengawasannya secara tidak memihak pada 
perusahaan sehingga pada saat pengungkapan informasi tentang keuangan akan disampaikan lebih banyak dan informasi akuntansi akan berkualitas tinggi serta efektif, maka $\mathrm{H}_{8}$ diterima.

Hasil signifikan terdapat 0,322 yang menunjukkan tidak adanya pengaruh signifikan antara keahlian dewan direksi dan penyajian kembali laporan keuangan. Direksi yang memiliki pengalaman kerja pada KAP besar memang akan sangat membantu dalam proses pembenaran data-data dan pengecekan pelaporan keuangan sehingga kesalahan yang ada bisa direvisi tetapi direksi yang memiliki pengalaman dalam KAP tersebut sangat terbatas orangnya mungkin dalam satu perusahaan tidak ada satu pun yang pernah bekerja pada KAP dan mungkin saja terdapat satu orang atau lebih dan direksi juga memiliki tugas yang banyak sehingga tidak bisa memantau laporan keuangan secara detail meskipun berpengalaman dalam KAP besar, sehingga h9 ditolak.

Hasil uji bernilai 0,054 yang menyatakan board size tidak mempengaruhi penyajian kembali laporan keuangan. Direksi pada sebuah perusahaan berfungsi sebagai orang yang membantu pemegang saham dalam mencapai misi dan visi yang sudah ditetapkan. Jumlah direksi yang banyak maupun sedikit tidak menjamin kemungkinan terjadinya restatement karena ketergantungan perusahaan dalam mengatur tanggung jawab dan peran direksi supaya dalam pengawasan bisa lebih efektif lagi maka $\mathrm{h}_{10}$ ditolak.

Nilai signifikan adalah 0,699 yang dapat dinyatakan tidak terdapat signifikan antara growth dan penyajian kembali laporan keuangan. Growth tidak memiliki pengaruh dikarenakan perusahaan akan tetap berkembang meskipun ada atau tidak adanya penyajian kembali laporan keuangan. Pertumbuhan disini melihat harga saham, harga saham yang ada pada perusahaan itu ditentukan sesuai dengan permintaan dan penawaran yang bersangkutan di pasar modal jadi tidak mempengaruhi penyajian kembali laporan keuangan, maka $\mathrm{H}_{11}$ ditolak.

\section{Kesimpulan dan Saran}

Tujuan dari penelitian ini guna menguji pengaruh independensi komite audit, pertemuan komite audit, ukuran komite audit, keahlian komite audit, leverage, jumlah anak perusahaan, jumlah anak perusahaan asing, persentase direktur non eksekutif, keahlian dewan direksi, board size, growth terhadap restatement laporan keuangan berdasarkan hasil penginputan data hingga sampai pengujian data.

Berdasarkan hasil uji menyatakan bahwa yang berpengaruh terhadap restatement laporan keuangan adalah variabel ukuran komite audit, jumlah anak perusahaan berpengaruh signifikan positif dan persentase direktur non eksekutif yang berpengaruh signifikan negatif. Dan variabel independensi komite audit, pertemuan komite audit, keahlian komite audit, leverage, jumlah anak perusahaan asing, keahlian dewan direksi, board size, dan growth menunjukan tidak mempengaruhi penyajian kembali laporan keuangan.

Pada penelitian selanjutnya diharapkan dapat menambahkan variabel independen lainnya untuk memperbanyak penelitian tersebut dan dapat memperluas sampel penelitian supaya tidak hanya berfokus pada satu negara saja tetapi juga Negara lain. 


\section{Referensi}

Abdullah, S. N., Yusof, N. Z. M., \& Nor, M. N. M. (2010). Financial restatements and corporate governance among Malaysian listed companies. Managerial Auditing Journal, 25(6), 526-552. https://doi.org/10.1108/02686901011054854

Amalia, B. Y., \& Didik, M. (2017). Pengaruh Konsentrasi Kepemilikan, Kepemilikan Institusional, Proporsi Dewan Komisaris Independen, dan Frekuensi Rapat Komite Audit terhadap Praktik Manajemen Laba. Diponegoro Journal of Accounting, 6(3), 393-406.

Amin, A. (2016). Independensi Komite Audit, Kualitas Audit dan Kualitas Laba : Bukti Empiris Perusahaan dengan Kepemilikan Terkonsentrasi. Jurnal Akuntansi Bisnis, 18(1), 1-14. https://doi.org/10.9744/jak.18.1.1-14

Apadore, K., \& Noor, M. M. (2013). Determinants of Audit Report Lag and Corporate Governance in Malaysia. International Journal of Business and Management, 8(15), 151-163. https://doi.org/10.5539/ijbm.v8n15p151

Ayu, P. P., \& Septiani, T. (2018). Pengaruh Ukuran Dewan Komisaris, Komite Audit, Dan Kap Terhadap Fee Audit Eksternal. Jurnal Akuntansi, 12(1), 1-15. https://doi.org/10.25170/jara.v12i1.55

Cristansy, J., \& Ardiati, A. Y. (2018). Pengaruh Kompleksitas Perusahaan, Ukuran Perusahaan, Dan Ukuran Kap Terhadap Fee Audit Pada Perusahaan Manufaktur Yang Terdaftar Di Bei Tahun 2012-2016. Modus, 30(2), 198-211. https://doi.org/10.24002/modus.v30i2.1747

Dwiharyadi, A. (2017). Pengaruh Keahlian Akuntansi Dan Keuangan Komite Audit Dan Dewan Komisaris Terhadap Manajemen Laba. Jurnal Akuntansi Dan Keuangan Indonesia, 14(1), 75-93. https://doi.org/10.21002/jaki.2017.05

Handoko, B. L., \& Ramadhani, K. A. (2017). Pengaruh Karakteristik Komite Audit, Keahlian Keuangan Dan Ukuran Perusahaan Terhadap Kemungkinan Kecurangan Laporan Keuangan. DeReMa (Development Research of Management): Jurnal Manajemen, 12(1), 86. https://doi.org/10.19166/derema.v12i1.357

Harijanto, V. N. A. (2019). Pengaruh Stuktur Kepemilikan dan Ukuran Kantor Akuntan Publik terhadap Tingkat Kepatuhan Pengungkapan Transaksi Berelasi Berdasarkan PSAK No 7 tentang Pengungkapan Pihak-Pihak Berelasi. Jurnal Nominal, VIII(7).

Hashim, U. J. B., \& Rahman, R. B. A. (2011). Audit report lag and the effectiveness of audit committee among malaysian listed companies. International Bulletin of Business Administration, 10(10), 50-61. Retrieved from https://www.scribd.com/doc/65902120/Audit-Report-Lag-and-theEffectiveness-of-Audit-Committee-Among-Malaysian-Listed-Companies

Hery. (2016). Financial Ratio For Business (Adipramono, ed.). Jakarta: PT Grasindo.

Ibrahim, A. M., \& Suryaningsih, R. (2016). Pengaruh profitabilitas, leverage, reputasi kap dan opini audit terhadap audit delay (Studi pada perusahaan sektor infrastruktur, utilitas dan transportasi selama periode 2012 - 2014). Ultima Accounting, 8(1), 1-21.

Immanuel, R., \& Yuyetta, E. N. A. (2014). Analisis Faktor-Faktor yang Mempengaruhi Penetapan Audit Fees (Studi Empirik pada Perusahaan Manufaktur di BEI). 3(1989), 816-827.

Indriantoro, N., \& Supomo, B. (2013). Metodologi Penelitian Bisnis Untuk Akuntansi \& Manajemen.

Jensen, M. C., \& Meckling, W. H. (1976). The Theory of the firm: Manajerial Behaviour, 
Agency Cost, and Ownership Structure, Journal of Financial and Economics.

Kusuma, B. I., \& Rohman, A. (2014). Analisis Mekanisme Corporate Governance Terhadap Probabilitas Terjadinya Earnings Restatement. 3(2), 248-262.

M, R. R. M., \& Laksito, H. (2017). Pengaruh Karakteristik Komite Audit Terhadap Kualitas Laba. 6(4), 429-439.

Mohammad, W. M. W., Wasiuzzaman, S., Morsali, S. S., \& Rapiah Mohd Zaini. (2018). The Effect of Audit Committee Characteristics on Financial Restatements in Malaysia. Journal of Asia-Pacific Business, 19(1), 4-22. https://doi.org/10.1080/10599231.2018.1419043

Pembayun, A. G., \& Januarti, I. (2012). Pengaruh Karakteristik Komite Audit terhadap Financial Distress. Wiley Encyclopedia of Management, 1, 1-3. https://doi.org/10.1002/9781118785317.weom040039

Puspitasari, D., \& Januarti, I. (2014). Pengaruh Keberadaan Wanita dalam Keanggotaan Keuangan Perusahaan ( Studi Empiris pada Perusahaan Non-financial yang Terdaftar di Bursa Efek Indonesia Tahun 2007-2012 ). Diponegoro Journal of Accounting, 8, 1-15.

Ridwan, \& Afriyenti, M. (2019). Pengaruh Kepemilikan Keluarga, Ukuran Dewan Direksi, Dan Proporsi Direktur Independen Terhadap Tingkat Pengungkapan Sukarela. Jurnal Eksplorasi Akuntansi, 1(3), 1376-1391. Retrieved from http://jea.ppj.unp.ac.id/index.php/jea/issue/view/12

Setiawan, I. G. A. N. A. P., \& Mahardika, D. P. K. (2019). Analisis Pengaruh Market To Book Value, Firm Size dan Profitabilitas terhadap Pengambilan Keputusan Lindung Nilai (Studi Kasus pada Perusahaan Sub Sektor Otomotif dan Komponennya yang Terdaftar di Bursa Efek Indonesia pada tahun 2014-2017). Jurnal Ilmiah Akuntansi, 4(1), 124-140. https://doi.org/10.23887/jia.v4i1.17055

Siregar, N. Y., \& Rahayu, F. (2018). Pengaruh Corporate Governance Terhadap Restatement dan Dampaknya Terhadap Harga Saham. 12(2).

Sugiyono. (2016). Metode Penelitian Kuantitatif, Kualitatif, dan R\&D. Bandung: Alfabeta. Tandungan, D., \& Mertha, I. M. (2016). Pengaruh Komite Audit, Ukuran Perusahaan, Audit Tenure, dan Reputasi KAP terhadap Opini Audit Going Concern. E-Jurnal Akuntansi, 16(1), 45-71.

Tribunnews. (2019). OJK Masih Dalami Laporan Keuangan Garuda Indonesia.

Widyaningrum, V. F., \& Faisal. (2015). Pengaruh Karakteristik Corporate Governance terhadap Penyajian Kembali Laporan Keuangan. Diponegoro Journal of Accounting, 4(2), 1-13. 